\title{
The Practice of the Re-Engineering of Administrative Processes Approach in Kindergarten Institutions in Jordan from the Perspective of Female Principals and Teachers
}

\author{
Dr. Reda S. Al-Mawdieh \\ Assoc. Prof., Zarqa University, Jordan
}

DOI: https://doi.org/10.36941/jesr-2020-0110

\section{Abstract}

This study aimed to reveal the extent to which the re-engineering of administrative processes approach is practiced in kindergarten institutions in Jordan from the perspective of female principals and teachers. The study applied a descriptive analytical methodology to achieve the research objectives. A questionnaire was developed to collect the data, from the study sample, which consisted of 61 female principals and 161 female teachers. The results showed that the overall mean for the degree of practicing the re-engineering of administrative processes approach in kindergarten institutions in Jordan from the perspective of female principals was high at 3.71 with a standard deviation of 0.52 . On the other hand, the overall mean for the degree of practicing the re-engineering administrative processes approach from the perspective of female teachers was medium at 3.52 with a standard deviation of o.6o. According to the results main recommendations were made, including: 1-working to spread and consolidate the concept of re-engineering administrative processes among employees in kindergarten institutions; 2- to establish a training system on the approach to the reengineering of administrative processes aimed at female principals and teachers in kindergarten institutions; 3- to conduct further studies in other kindergarten institutions and samples to broaden knowledge on the subject addressed by the present study.

Keywords: Kindergarten institutions, Re-engineering administrative processes, Female teacher, Jordan

\section{Introduction}

During 21 century, the global perspective has shifted and due to prevailing lifestyle changes a new civilization is emerging. This civilization, which has been described as the "third wave" or "information age" is witnessing rapid change and modernization. However, the human element remains at the dynamic axis of change.

Therefore, since the beginning of the third millennium, many nations have reviewed their actions, evaluated their performance and achievements, analysed their strengths and weaknesses, identified development opportunities and their options to enhance the positives and avoid the negatives. The outcome of this period of reflection has led many developed nations to realize that achieving this position is only possible through education the younger generations with in an integrated manner and providing them with the information base, life skills, practical experiences and behavioural values that will enable them to adapt to modern developments and face upcoming challenges effectively. This realization explains why many countries around the world are interested in constantly reviewing their educational and teaching systems, and assessing their ability to prepare upcoming generations for 
twenty-first century society (Hussein \& Mohamed, 2008).

As kindergarten institutions are the first educational setting that the younger generation experiences, they urgently need to reconsider their policies, goals, contents, methods, programs, and management so that the educational system can be utilized as a tool for change and development to enable society to meet the challenges of the twenty-first century. This can be achieved by following various educational approaches to achieve improved communication with children. So, this shows the importance of changing the standard. (Al -Asar, 2001).

Ayasarah and Al-Fadil (2006) emphasized that kindergarten institutions represent a vital tool in society and therefore they need to undergo a process of reform and continuous development because they are the key starting point for the process of educational reform and development through which the needs and aspirations of society can be addressed. Consequently, there is an urgent need to cause a fundamental shift in traditional management practices in such institutions so that they embrace patterns of working that are flexible and, innovative and that can respond to future developments and events.

In response to the foregoing, the concept of the re-engineering administrative processes can be considered one of the entry points for change. This concept focuses on the rapid redesign of strategic and value- added management processes to achieve radical change. This approach focuses on adapting systems, policies and structures, in order to improve performance and increase productivity in educational institutions and increase customer satisfaction (Al-Qaryouti, 200).

Therefore, the re-engineering of administrative processes approach can be considered a reform approach that aims to radically change the performance of educational institutions, including kindergarten institutions, by enhancing and adopting concepts and practices that govern their work.

The scope of change encompasses many aspects such as practices, systems, policies and organizational structure. It also includes the re-orientation of employees in kindergarten institutions, and re-training them on new concepts and practices. This approach depends on the knowledge structure as a way to measure the added value. The radical change promoted by administrative reengineering aims to increase the ability of kindergarten institutions to respond to environmental change surrounding the institution, to improve working practices and to increase efficiency (Khalil, 2014).

In light of the foregoing, kindergarten institutions in all countries, including those in Jordan, which is the context of the present study need principals and teachers who possess the necessary leadership skills and competencies to enable them to fully exercise their roles and perform their tasks and work to meet the administrative and technical needs of the educational institution. They also need to educate their students in line with the educational policy and vision adopted by the Ministry of Education. In the case of Jordan, this vision includes a reshaping of the educational model to focus on leadership and administration strategies that are based on optimal use of the information and other forms of contemporary technology that is provided to enable change to take root in kindergarten institutions.

Therefore, kindergarten institutions like other organizations need a strategy for implementing re-engineering administrative processes that contribute to raising outputs at all levels and help in achieving the goals of the institution. The researcher believes that there is a need to change the role of kindergarten institutions in Jordan according to the re-engineering of administrative processes approach, and this belief motivated the researcher to investigate this issue further in the context of Jordan.

\section{Previous Studies}

Before embarking on the present study, some relevant studies conducted in Arab and other contexts were reviewed. A brief overview of these studies is presented below in ascending chronological order.

The first relevant study of note is that by Thomas \& Margaret (2003), who conducted a study in Singapore which was aimed at identifying the degree of application of the principles of administrative 
re-engineering in educational reform at the primary and secondary school levels. The study sample consisted of 125 schools: 77 primary and 48 secondary. A questionnaire was used to collect the data. The results showed that both primary and secondary education should be enhance by related parties and use the best methods related to technology in educational sector as well as to aim using reengineering was to make various changes in work systems, organizational structures, and administrative systems, and anything related to the re-engineering process should be renewed and, integrated with other processes. The study concluded that the re-engineering of administrative processes can be seen as a model that should be taken in to consideration to reform the educational system.

In the Arab context, Al-Dailani (2009) conducted a study aimed at monitoring the reality of administration performance in schools in Kuwait in order to try, to propose a vision for the application of the administrative re-engineering approach in school administration in the country. The descriptive methodology was used to describe the reality of school administration performance and the extent which it would be possible to apply the administrative re-engineering approach in administrative operations. The study sample consisted of male and female principals of schools in Kuwait. The most important results of the study indicated the existence of obstacles in the areas of curriculum management, professional development of teachers and management of financial resources, which called for adoption of school restructuring, rebuilding, change at the school level, adoption of participative management, introduction of school-centred administration, education to increase understanding and creativity and an increase in the amount of authority delegated to teachers.

In another study that was undertaken in the Arab context, Rajabion, et al (2010) attempted to propose a re-engineering processes model for educational institutions in general and kindergarten institutions in particular in Saudi Arabia. The model defines the problems of the administrative system and provides a solution (re-engineering) that can be used as a reference in similar projects. The interview method was used to collect data. The study sample consisted of the department directors in schools and kindergarten institutions in Riyadh. The most important results of the study showed that there were three practical steps that need to be taken. The first main step is to study the outline of the organizational structure and its basic functions. The second is to provide a model of the current engineering process. The third is to provide a model for re-engineering processes and educational processes, which involves eliminating all redundancies and excess resources, employing technical solutions and re-engineering and non-integrated administrative entities. Thus, the development perfect model in all administrative processes can use as a reference for schools in other countries in the Middle East.

On the other hand, Hanoun (2010) undertook a study in the west bank, Palestine, which was aimed identifying the extent to which the administrative engineering method was being used in practicing administrative processes in public schools in the West Bank governorates from the perspective of male and female principals. In addition, the study also looked into the effect of several variables, namely: sex, academic qualification, managerial experience, level of study, specialization, and governorate, on the responses of male and female principals. The descriptive analytical methodology was used and the study was conducted on an available sample of 488 principals. One of the most important results that the study reported is that the degree of using the re -engineering method in public schools in the West Bank governorates was very high among both male and female principals.

In other study conducted in Palestine, Rayhan (2014), aimed to identify the obstacles to applying administrative process engineering in public schools in the governorates of Gaza and ways to reduce them. The descriptive analytical methodology was used and a questionnaire was developed to collect data. The questionnaire consisted of 60 items, distributed across four dimensions. The study population consisted of all 398 male and female principals of public schools in the governorates of Gaza in the school year (2013-2014). The results of the study showed that school principals faced obstacles when applying the re-engineering approach to a high degree, with a relative mean of (59.73).

The review of aforementioned previous studies, revealed some of the administrative issues in educational institutions and a variety of different variables, and that a range, of scientific research 
methods were used to investigate them. These methods included the descriptive survey method, the descriptive analytical methodology and quantitative research. The above were considered in the development of the methodology adopted to address the problem identified in this study, namely, the degree of practicing the re-engineering of administrative processes approach in kindergarten institutions from the perspective of female principals and teachers.

\section{The Study Problem}

The complexity of contemporary global challenges makes it imperative for educational institutions to adopt conscious scientific method in facing these challenges. So, the complexity of contemporary global challenges makes it imperative for educational institutions to adopt conscious scientific method in facing these challenges, and train the human powers in efficient and effective way. However, one of the most targeted is achieving to new approach called (Engineering of Administrative Processes), which today, thanks to a vast amount of information and communication techniques, has become a unique characteristic for humans and their thought. Thus, this is can be seen it in educational institutions (Mohammad Ziyad, 2009).

The kindergarten institutions in the Arab world in general are still in the developmental stage, so it is necessary to intensify efforts and reconsider this basic pillar of education, because it is a cornerstone in preparing good citizens and refining aspects of children's personality and preparing them so that they are able to complete the stages of study that follow the kindergarten stage. The kindergarten is the first core and needs to continue develop and support all continuously. Therefore, in order to deliver a quality education, kindergarten institutions need to employ systematic planning, coordinated education programs, and conscious management, as well as invest in the continuous training and professional growth of their teachers (Mahamdah, 2005).

It is considered that the re-engineering of administrative processes is one of the ways in which to drive the necessary change to achieve the aforementioned goals. This concept focuses on the rapid redesign and radical change of strategic administrative processes. This redesign focuses on systems, policies, and organizational structures with the aim of improving performance and the overall quality of education. In order to discover the reality on the ground regarding the application of this concept in Jordanian kindergarten institutions, the current study aimed to answer the following two main questions:

1. What is the degree of practicing the re-engineering of administrative processes approach in kindergarten institutions in Jordan from the perspective of female principals and teachers?

2. Are there any significant differences at $(\alpha \leq 0.05)$ in the degree of practicing the reengineering of administrative processes approach in kindergarten institutions that are attributable to the academic qualification and experience variables?

\section{Objectives of the Study}

The present study aimed to:

- Determine the reality of kindergarten institutions in light of the re-engineering of administrative processes approach from the perspective of female principals and teachers.

- Detect whether there are any differences between the perspective of the individuals in the study sample according to academic qualification and experience.

\section{Importance of the Study}

This study is important for the following reasons:

- It presenting a clear road to deal with the issue related to administrative processes as a unique administrative approach which allows changing the role of kindergarten institutions in Jordan. 
- It provides feedback to the top leadership on the role of kindergarten institutions and identifies their strengths and weaknesses.

- It formulates and quick response the global and local initiatives in developing kindergarten institutions.

- It allows researchers to re-do the study by using the re-engineering administrative processes in kindergarten institutions.

- It enriches Arabic research knowledge by providing evidence on the kindergarten institutions in Jordan in regard to their adoption of re-engineering of administrative processes as an approach to facilitate change.

\section{Conceptual and Operational Definitions}

6.1 Conceptual definitions

* Kindergarten institutions: This term is universally applied to a group of educational experiences among children before they enter elementary classes in school. This term is also used to refer to the raising of children aged (4-5) years old, according to the requirements for admission to schools in the Middle East region (Hutaiba, 2006). In Jordan, it is defined in law according to the Ministry of Education in Jordan (1994) as a social educational institution in which the child spends some of the day in varied activities that help him/her to achieve integrated growth when they are in the age group of approximately (4-6) years old (Ministry of Education, 2019).

* Re-engineering administrative processes: This term is defined as one of the entry points for change, which focuses on the rapid redesign and radical change of strategic and value added administrative processes, as well as systems, policies, and organizational structures with the aim of improving performance and increasing productivity in the organization and increasing the satisfaction of beneficiaries (Al-Hamidi,Salma \& Kafi, 2016).

* Operational definition: It is the planned change that aims to modify the administrative processes in kindergarten institutions, the methods of working and the behaviour of their members of staff, so that the institution can quickly adapt to the changes that occur in its internal and external environment.

\section{Limitations of the Study}

The study was limited to female principals and teachers in kindergarten institutions in Zarqa Governorate who participated in the study during the second semester of the academic year (20192020). The results of this study are based on the responses of sample subjects to the questionnaire items prepared for the purpose of this study.

\section{Methodology}

In this study, the descriptive analytical methodology was adopted, which included a desk survey that involved referring to references and resources to build the theoretical framework for the study, and a field survey to collect data by means of a study tool (questionnaire) and statistically analysing the obtained data to answer the study questions.

\subsection{Study Population}

The study population consisted of female principals and teachers in kindergarten institutions in the education directorates of Zarqa Governorate during the academic year 2019/2020. The study population consisted of 61 female principals and 1072 female teachers. 


\subsection{Study Sample}

The study sample was the same as the study population. With regard to kindergarten principals, the sample contained 61 female principals. The questionnaire was distributed to all subjects in the sample, from whom 54 questionnaires were retrieved. There of those questionnaires were excluded because they were not valid for statistical analysis. Therefore, 51 valid questionnaires were included in the analysis, which represented a response rate of $83.60 \%$ for female principals of kindergarten institutions.

As for the kindergarten teachers, a simple random sample was drawn at a rate of $15 \%$. From the resulting sample size of 161,136 questionnaires were retrieved. Four of those questionnaires were excluded, because they were not valid for statistical analysis. Therefore, 132 valid questionnaires were included in the analysis, which equated to a $81.98 \%$ for female teachers in kindergarten institutions.

\subsection{The Study Tool}

A questionnaire was developed to measure the progress of kindergarten institutions in Jordan, in light of the re-engineering of administrative processes approach from the perspective of female principals and teachers. The questionnaire consisted of two parts.

The first part consisted of two questions designed to obtain the necessary demographic information about the respondents, namely, experiences and academic qualification.

The second part contained the questionnaire that was used to measure the degree of practicing the re-engineering of administrative processes approach in Jordanian kindergarten institutions as perceived by the female principals and teachers. The questionnaire items were based on those found in Rajabion, et. al. (2010) and Thomas and Margaret (2003). The answers to the items in the questionnaire were based on a five-point Liker-type scale, where (1) indicated that the approach was perceived to be practiced to a very weak degree,(2) a weak degree, (3) a medium degree, (4) a great degree and (5) a very large degree.

Therefore, if the mean value is greater 3.67, then the perception of the degree of practicing the approach is high; if the mean value is between 2.34 and 3.66, the degree is medium; and if the mean value is less than 2.33, the degree of perceptions is low. All these results depend on the (the higher value - the lowest value) criterion.

\subsection{Validity of the study tool}

Prior to its use, the questionnaire tool was presented to a number of arbitrators, including professors of educational administration in Jordanian universities, as well as female principals, teachers and educational supervisors, in order to ensure the validity of the questionnaire items. The arbitrators were asked to give their assessment of the clarity of the items, the quality of their language used to formulate the items, and the affiliation of the items with the dimension in which they were placed. They were also asked to amend or delete any of the items in order to achieve the desired goal of the study. The Items of questionnaires were redesigned to become agreed by $80 \%$ of the arbitrators. Thus, some of the items were modified and three were deleted. The final version of the tool consisted of 30 items.

\subsection{Reliability of the study tool}

The reliability coefficients for the four dimensions were extracted using the Cronbach's alpha equation for internal consistency. These coefficients were obtained by conducting a pilot study on 25 respondents who were not part of the main study sample. The results of reliability testing are as shown in Table (1). 
Table (1): Reliability of the study tool using Cronbach's alpha

\begin{tabular}{|c|c|c|}
\hline Item numbers in questionnaire & Dimension & Reliability coefficient \\
\hline $1-8$ & Planning & 0.88 \\
\hline $9-16$ & Organisation & 0.89 \\
\hline $17-24$ & Guidance & 0.87 \\
\hline $25-30$ & Monitoring and follow up & 0.90 \\
\hline $1-30$ & Whole questionnaire & 0.91 \\
\hline
\end{tabular}

From Table (1), it is clear that the reliability coefficients for all four dimensions of the study and for the questionnaire as a whole were high. As all the values were above the acceptable threshold of x.xx (ref) for this type of study, this indicated that questionnaire was suitable, for use in the main study.

\subsection{Statistical processing}

Descriptive statistics measures were used to answer the first study question. These measures included the mean and standard deviation. On the other hand, multivariate analysis and the Scheffe test for statistically significant variables were used to answer the second study question.

\section{Results and Discussion}

9.1 The first question: What is the degree of practicing the re-engineering of administrative processes approach in kindergarten institutions in Jordan from the perspective of female principals and teachers'?

To answer the first study question, the means and standard deviations were calculated for each dimension of the study instrument. The results are presented in Table (2).

Table (2): Means, standard deviations, and ranks for the dimensions of the re-engineering of administrative processes approach in kindergarten institutions in Jordan from the perspective female principals and teachers'

\begin{tabular}{|c|l|c|c|c|c|c|c|c|c|}
\hline \multirow{2}{*}{ Item numbers } & \multirow{4}{*}{ Dimension } & \multicolumn{4}{|c|}{ Principals } & \multicolumn{4}{c|}{ Teacher } \\
\cline { 2 - 10 } & & Mean & S.D & Rank & Degree & Mean & S.D & Rank & Degree \\
\hline $1-8$ & Planning & 3.85 & 0.53 & 1 & High & 3.58 & 0.59 & 1 & Medium \\
\hline $9-16$ & Organization & 3.75 & 0.56 & 2 & High & 3.56 & 0.63 & 2 & Medium \\
\hline $17-24$ & Guidance & 3.65 & 0.59 & 3 & Medium & 3.52 & 0.65 & 3 & Medium \\
\hline $25-30$ & Monitoring and follow-up & 3.62 & 0.61 & 4 & Medium & 3.44 & 0.67 & 4 & Medium \\
\hline $1-30$ & Total & 3.71 & 0.52 & - & High & 3.52 & o.6o & - & Medium \\
\hline
\end{tabular}

S.D. = standard deviation

From Table (2), it can be seen that the degree of practicing the re-engineering of administrative processes in kindergarten institutions in Jordan was high from the perspective of female principals' with an overall mean of 3.71 and a standard deviation 0.52. The ranking of the dimensions, in descending order, was as follows: Planning, was ranked first with a mean of 3.85 and a standard deviation of (o.53), followed by organization with a mean of 3.72 and a standard deviation of 0.56 ranked second, while guidance was in the third place with a mean of 3.65 and a standard deviation of 0.59 , and in the last place, ranked fourth, was monitoring and follow-up, with a mean of 3.62 and a standard deviation of (o.61).

On the other hand, Table (2) also shows that the degree of practicing the re-engineering of administrative processes approach from the perspective of female teachers was medium, with a mean of 3.52 and a standard deviation of (o.6o).

However, the dimensions were ranked in the same descending order as follows: Planning a mean 
of was 3.58 and a standard deviation of 0.59 , organization, with a mean of 3.56 and a standard deviation of 0.63 , guidance with a mean of 3.52 and a standard deviation of 0.65 , and monitoring and follow-up with a mean of 3.44 and a standard deviation of 0.67 .

These results may be attributed to generation the idea of applying the re-engineering administrative processes. This is evidence of an acceptance of the idea of change among female principals and teachers of kindergarten institutions as a result of global and national initiatives that encourage a focus on changing the role of kindergarten institutions according to the requirements of the times. In addition, the related parties such as Ministry of Education care to conduct difference educational conferences, seminars, and workshops for their employees and monitor all these procedures by the Ministry of Quality and Accountability unit. This finding is consistent with Hanoun (2010).

However, despite this result, the responses of the respondents indicate that they believe that more time and effort is still needed to address the issue of administrative re-engineering in order to enable to reach kindergarten institutions advanced levels. This perception is to be expected, given that administrative re-engineering is a broad and comprehensive process that encompasses all the facilities and activities of public and private kindergarten institutions. This is consistent with Thomas and Margaret (2003).

In order to further clarify the views held by female kindergarten principals and teachers, the following subsections provide a detailed description of the results for each of four dimensions of the practice of the re-engineering of administrative processes approach.

$\checkmark$ Planning as a dimension of administrative re-engineering to develop kindergarten institutions in Jordan.

Table (3): Means, standard deviations and degrees for the planning dimension of the re-engineering of administrative processes approach to develop kindergarten institutions in Jordan from the perspective of female principals and teachers

\begin{tabular}{|c|c|c|c|c|c|c|c|}
\hline \multirow[b]{2}{*}{ No. } & \multirow[b]{2}{*}{ Item } & \multicolumn{3}{|c|}{ Principals } & \multicolumn{3}{|c|}{ Teachers } \\
\hline & & Mean & $\begin{array}{l}\text { Standard } \\
\text { deviation }\end{array}$ & Degree & Mean & $\begin{array}{l}\text { Standard } \\
\text { deviation }\end{array}$ & Degree \\
\hline 1 & $\begin{array}{l}\text { The kindergarten seeks to spread the culture of } \\
\text { change through various means. }\end{array}$ & 3.94 & 0.95 & High & $3 \cdot 77$ & 0.94 & High \\
\hline 2 & $\begin{array}{l}\text { The kindergarten has the ability to plan ahead } \\
\text { according to a clearly defined vision. }\end{array}$ & 3.96 & 0.93 & High & $3 \cdot 75$ & 0.97 & High \\
\hline 3 & $\begin{array}{l}\text { The kindergarten provides an accurate description } \\
\text { of its operations, according to a public mission. }\end{array}$ & 3.88 & 0.97 & High & 3.69 & 0.99 & High \\
\hline 4 & $\begin{array}{l}\text { The kindergarten determines the functional tasks of } \\
\text { its members of staff according to specific instructions. }\end{array}$ & 4.26 & 0.91 & High & $3 \cdot 72$ & 0.99 & High \\
\hline 5 & $\begin{array}{l}\text { The kindergarten determines its goals in a } \\
\text { measurable and evaluative way. }\end{array}$ & 3.78 & 0.98 & High & 3.40 & 1.08 & Medium \\
\hline 6 & $\begin{array}{l}\text { The kindergarten seeks to analyse the internal } \\
\text { environment to identify strengths and weaknesses. }\end{array}$ & 3.61 & 1.01 & Medium & $3 \cdot 39$ & 1.09 & Medium \\
\hline 7 & $\begin{array}{l}\text { The kindergarten seeks to analyze the external } \\
\text { environment to identify external threats. }\end{array}$ & 3.81 & 0.99 & High & 3.60 & 1.09 & Medium \\
\hline 8 & The kindergarten has its own budget. & $3 \cdot 56$ & 1.03 & Medium & $3 \cdot 35$ & 1.10 & Medium \\
\hline \multicolumn{2}{|r|}{ Total score } & 3.85 & 0.53 & High & 3.58 & 0.59 & Medium \\
\hline
\end{tabular}

From Table (3), the overall mean of the items in the planning dimension for the development of kindergarten institutions in Jordan in light of the re-engineering of administrative processes approach from the female principals' perspective was 3.85 with a standard deviation of 0.53 . This result indicates that they perceive that the planning dimension receives a high degree of attention. Item 4 , which states that "The Kindergarten determines the functional tasks of its members of staff according to specific instructions," was ranked first with a mean of 4.26 and a standard deviation of 0.91 . On the other hand, 
item 8, which states that "The kindergarten has its own budget," was ranked last, with a mean of 3.56 and a standard deviation of 1.03 .

From Table (3), it can be seen that the overall mean of the items of the planning dimension from the perspective of female teachers was 3.58 with a standard deviation of 0.59 , which indicates that they believe that planning receives a moderate amount of attention. Item 1, which states that "The Kindergarten seeks to spread the culture of change through various means," was ranked first with a mean of 3.77 and a standard deviation of 0.94 . Item 8 which states that "The Kindergarten has its own budget," was ranked last, with a mean of 3.35 and a standard deviation of 1.10.

The result for the female principals may be attributed to the presence of a more efficient administrative cadre that contributes to achieving the functions of kindergarten institutions and promoting them by spreading the culture of change in the institution, which is supported by the principals having an awareness of good planning methods for kindergarten institutions. The result is also an indication of the extent to which the principals observe modern administrative trends. In addition, the ISO system is implemented in kindergarten institutions, which involves the continuous scrutiny by senior management, and the implementation and follow-up of an annual plan for kindergarten institution administration. This result differs with Al-Daihani (2009) but is in agreement with Hanoun (2010).

However, the female kindergarten teachers perceive that some departments need to make more efforts in regard to planning, for example, by simplifying some organizational structures and job tasks also by organizing educational and awareness sessions about the importance of a culture of change in kindergarten institutions as well as enhancing the interaction between the educational parties in the institutions to build the perfect system for the institution. This would require higher management to participate and collaborate with female teachers and principals in developing plans and following up the implementation of these plans. This is consistent with Thomas and Margaret (2003).

$\checkmark$ Organization as a dimension of administrative re-engineering to develop kindergarten institutions in Jordan.

Table (4): Means, standard deviations and degrees for the organization dimension of the reengineering of administrative processes approach to develop kindergarten institutions in Jordan from the perspective of female principals and teachers

\begin{tabular}{|c|c|c|c|c|c|c|c|}
\hline \multirow[b]{2}{*}{ No. } & \multirow[b]{2}{*}{ Item } & \multicolumn{3}{|c|}{ Principals } & \multicolumn{3}{|c|}{ Teachers } \\
\hline & & Mean & $\begin{array}{l}\text { Standard } \\
\text { deviation }\end{array}$ & Degree & Mean & $\begin{array}{l}\text { Standard } \\
\text { deviation }\end{array}$ & Degree \\
\hline 9 & $\begin{array}{l}\text { The kindergarten adopts the working team's style in } \\
\text { its procedures. }\end{array}$ & 3.66 & 0.98 & Medium & 3.39 & 1.09 & Medium \\
\hline 10 & $\begin{array}{l}\text { The kindergarten uses an electronic management } \\
\text { system in its administrative processes. }\end{array}$ & $3 \cdot 54$ & 1.04 & Medium & $3 \cdot 57$ & 1.06 & Medium \\
\hline 11 & $\begin{array}{l}\text { The kindergarten provides a cooperative climatefor } \\
\text { its members of staff which encourages cooperation } \\
\text { between them. }\end{array}$ & 3.81 & 0.96 & High & 3.84 & 0.96 & High \\
\hline 12 & $\begin{array}{l}\text { The kindergarten enhances effective communication } \\
\text { between the communities. }\end{array}$ & $3 \cdot 96$ & 0.92 & High & 3.74 & 0.95 & High \\
\hline 13 & $\begin{array}{l}\text { In kindergarten activities to gain its members of } \\
\text { staff the bio skills. }\end{array}$ & 3.68 & 0.97 & High & 3.55 & 1.04 & Medium \\
\hline 14 & $\begin{array}{l}\text { The kindergarten identifies the training needs of its } \\
\text { members of staff in accordance with a practical plan. }\end{array}$ & $3 \cdot 57$ & 1.04 & Medium & 3.09 & 1.13 & Medium \\
\hline 15 & $\begin{array}{l}\text { The kindergarten seeks to constantly improve its } \\
\text { administrative processes. }\end{array}$ & 3.82 & 0.98 & High & 3.69 & 0.99 & High \\
\hline 16 & $\begin{array}{l}\text { The kindergarten works on file archives in a way } \\
\text { that is easily accessible. }\end{array}$ & 3.74 & 0.94 & High & 3.61 & 1.05 & Medium \\
\hline \multicolumn{2}{|r|}{ Total score } & $3 \cdot 72$ & 0.56 & High & $3 \cdot 56$ & 0.63 & Medium \\
\hline
\end{tabular}


Table (4) shows that the overall mean of the items in the organization dimension for the development of kindergarten institutions in Jordan in light of the re-engineering of administrative processes approach from the viewpoint of female principals was 3.72 with a standard deviation of 0.56 . This indicates that they perceive that the organization dimension is given a high degree of attention. Item 12, which states that "The kindergarten enhances effective communication between the communities," was in first place with a mean of 3.96 and a standard deviation of 0.92 . On the other hand, item 10, which states that "The kindergarten uses an electronic management system in its administrative processes", was in last place, with a mean of 3.54 and a standard deviation of 1.04.

Table (4) also shows that the overall mean for the items of the organization dimension from the female teachers' perspective was 3.56 with a standard deviation of 0.63 . This indicates that they hold the opinion that organization is receiving moderate attention. Item 11, which states that "The kindergarten provides a cooperative climate for its members of staff that encourages cooperation between them," was ranked first, with a mean of 3.84 and a standard deviation of 0.96. Item 14, which states that "The kindergarten identifies the training needs of its members of staff in accordance with a practical plan," was ranked last with a mean of 3.09 and a standard deviation of 1.13.

The result for the female principals may be attributed to their awareness of the importance of the organization dimension through the formation of work teams in kindergarten institutions that encourage the building of a cooperative climate between employees, which facilitates the process of administrative and technical communication within the kindergarten institution system. This in turn, has a great impact on simplifying some procedures among employees. In addition, according to the beliefs of kindergarten principals, it is important to utilize an electronic system to complete transactions and to be able to refer to them in an easy way. So, the continuous improvement by identifying the training needs of members of staff first hand. This is consistent with Hanoun (2010).

However, from the result for the female kindergarten teachers, it seems that they look at the linkages between the various administrative processes because the reality of the organizational process is related to the reality of planning in kindergarten institutions. Therefore, they believe that the competent authorities need to invest more time and effort in organization dimension in order to simplify administrative procedures for the members of staff of kindergarten institutions as well as to spread the culture of utilizing an electronic system in kindergarten institutions through the provision of training courses and advertising to show the way of dealing with the system.

This requires senior management to define the training needs of members of staff first hand to ensure continuous improvement. This is consistent with Thomas and Margaret (2003), Al-Daihani (2009) and Rayhan (2014).

$\checkmark$ Guidance as a dimension of administrative re-engineering to develop kindergarten institutions in Jordan

Table (5): Means, standard deviations and degrees for the guidance dimension of the re-engineering of administrative processes approach to develop kindergarten institutions in Jordan from the perspective of female principals and teachers

\begin{tabular}{|c|c|c|c|c|c|c|c|}
\hline \multirow[b]{2}{*}{ No. } & \multirow[b]{2}{*}{ Item } & \multicolumn{3}{|c|}{ Principals } & \multicolumn{3}{|c|}{ Teachers } \\
\hline & & Mean & $\begin{array}{l}\text { Standard } \\
\text { deviation }\end{array}$ & Degree & Mean & $\begin{array}{l}\text { Standard } \\
\text { deviation }\end{array}$ & Degree \\
\hline 17 & $\begin{array}{l}\text { The kindergarten is concerned with applying } \\
\text { modern educational methods through the use of } \\
\text { social media. }\end{array}$ & $3 \cdot 77$ & 0.98 & High & $3 \cdot 70$ & 0.97 & High \\
\hline 18 & $\begin{array}{l}\text { The kindergarten schedules periodic meetings } \\
\text { between its members of staff. }\end{array}$ & 3.61 & 1.01 & Medium & $3 \cdot 36$ & 1.04 & Medium \\
\hline 19 & $\begin{array}{l}\text { The kindergarten is following the stages of } \\
\text { implementing its strategic plan according to a } \\
\text { timetable. }\end{array}$ & $3 \cdot 53$ & 1.05 & Medium & 3.44 & 1.07 & Medium \\
\hline
\end{tabular}




\begin{tabular}{|c|c|c|c|c|c|c|c|}
\hline \multirow[b]{2}{*}{ No. } & \multirow[b]{2}{*}{ Item } & \multicolumn{3}{|c|}{ Principals } & \multicolumn{3}{|c|}{ Teachers } \\
\hline & & Mean & $\begin{array}{l}\text { Standard } \\
\text { deviation }\end{array}$ & Degree & Mean & $\begin{array}{l}\text { Standard } \\
\text { deviation }\end{array}$ & Degree \\
\hline 20 & $\begin{array}{l}\text { The kindergarten provides a work-friendly } \\
\text { environment. }\end{array}$ & 3.80 & 0.94 & High & 3.69 & 0.97 & High \\
\hline 21 & $\begin{array}{l}\text { The kindergarten constantly reviews its plans and } \\
\text { programs in line with current developments. }\end{array}$ & 3.48 & 1.06 & Medium & 3.40 & 1.09 & Medium \\
\hline 22 & $\begin{array}{l}\text { The kindergarten is committed to the principle of } \\
\text { decentralization. }\end{array}$ & $3 \cdot 47$ & 1.08 & Medium & 3.23 & 1.12 & Medium \\
\hline 23 & $\begin{array}{l}\text { The kindergarten offers its members of staff } \\
\text { opportunities for professional development fairly } \\
\text { and transparently. }\end{array}$ & 3.70 & 0.99 & High & 3.68 & 0.99 & High \\
\hline 24 & The kindergarten employs targets to prioritize. & 3.83 & 0.89 & High & 3.64 & 1.06 & Medium \\
\hline \multicolumn{2}{|r|}{ Total Score } & 3.65 & 0.59 & Medium & $3 \cdot 52$ & 0.65 & Medium \\
\hline
\end{tabular}

From Table (5), the overall mean of the items in the guidance dimension for the development of kindergarten institutions in Jordan in light of the re-engineering of administrative processes approach from the perspective of female principals was 3.65 with a standard deviation of 0.89 . This result indicates that they have a medium level of interest in this dimension. Item 24, which states that "The kindergarten employs targets to prioritize," was ranked first with a mean of 3.83 and a standard deviation of 0.59. On the other hand, item 22, which states that "The kindergarten is committed to the principle of decentralization," was ranked last, with a mean of 3.47 and a standard deviation of 1.o8.

Table (5) also shows that the overall mean for the items of the guidance dimension from the female teachers' perspective was 3.52 with a standard deviation of 0.65 , which indicates that they have a medium level of interest in this dimension. Item 17, which states that "The kindergarten applies modern educational methods through the use of social media, was ranked in first place with a mean of 3.70 and a standard deviation of 0.97. Item 22 which states that "The kindergarten is committed to the principle of decentralization," was ranked last with a mean of 3.23 and a standard deviation of 1.12.

The results show that both female principals and female teachers are of the opinion that the competent authorities need to put more time and effort into the guidance dimension by holding regular periodic meetings at suitable times, because the preoccupation of the teachers throughout the day with the children, as well as the teaching and family burden off members of staff of kindergarten institutions, hinder the implementation process. This may be attributed to the lack of delegation of some responsibilities to the system by the senior management of female principals, and by female principals to female teachers. That hinders change in kindergarten institutions. This is consistent with Thomas and Margaret (2003) and Rajabion, et.al. (2010).

$\checkmark$ Monitoring and follow-up as a dimension of administrative re-engineering to develop of kindergarten institutions in Jordan:

Table (6): Means, standard deviations and degrees for the monitoring and follow-up dimension of the re-engineering of administrative processes approach to develop kindergarten institutions in Jordan from the perspective of female principals and teachers

\begin{tabular}{|c|c|c|c|c|c|c|c|}
\hline \multirow[b]{2}{*}{ No. } & \multirow[b]{2}{*}{ Item } & \multicolumn{3}{|c|}{ Principals } & \multicolumn{3}{|c|}{ Teachers } \\
\hline & & Mean & $\begin{array}{l}\text { Standard } \\
\text { deviation }\end{array}$ & Degree & Mean & $\begin{array}{l}\text { Standard } \\
\text { deviation }\end{array}$ & Degree \\
\hline 25 & $\begin{array}{l}\text { The kindergarten is keen to hold educational } \\
\text { lectures for female teachers. }\end{array}$ & 3.81 & 0.94 & High & 3.28 & 1.14 & Medium \\
\hline 26 & $\begin{array}{l}\text { The kindergarten uses a monitoring system that } \\
\text { increases the effectiveness of its members of staff. }\end{array}$ & 3.44 & 1.09 & Medium & $3 \cdot 52$ & 1.06 & Medium \\
\hline 27 & $\begin{array}{l}\text { The kindergarten is subject to the standards of } \\
\text { private entities. }\end{array}$ & $3 \cdot 51$ & 1.08 & Medium & $3 \cdot 57$ & 1.07 & Medium \\
\hline
\end{tabular}




\begin{tabular}{|c|c|c|c|c|c|c|c|}
\hline \multirow[b]{2}{*}{ No. } & \multirow[b]{2}{*}{ Item } & \multicolumn{3}{|c|}{ Principals } & \multicolumn{3}{|c|}{ Teachers } \\
\hline & & Mean & $\begin{array}{l}\text { Standard } \\
\text { deviation }\end{array}$ & Degree & Mean & $\begin{array}{l}\text { Standard } \\
\text { deviation }\end{array}$ & Degree \\
\hline 28 & $\begin{array}{l}\text { Corrective measures are available in the } \\
\text { kindergarten. }\end{array}$ & 3.69 & 1.00 & High & $3 \cdot 54$ & 1.08 & Medium \\
\hline 29 & The kindergarten has evaluation standards. & 3.62 & 1.03 & Medium & $3 \cdot 39$ & 1.09 & Medium \\
\hline 30 & $\begin{array}{l}\text { The kindergarten has credibility in the evaluation } \\
\text { process. }\end{array}$ & 3.66 & 1.01 & Medium & 3.36 & 1.10 & Medium \\
\hline \multicolumn{2}{|r|}{ Total score } & 3.62 & 0.61 & Medium & 3.44 & 0.67 & Medium \\
\hline
\end{tabular}

Table (6) shows that the overall mean of the items in the monitoring and follow-up dimension for the development of kindergarten institutions in Jordan in light of the re-engineering of administrative processes approach from the female principals' perspective was 3.62 with a standard deviation of 0.61 . This indicates that they believe that this dimension is receiving moderate attention. Item 25 , which states that "The kindergarten is keen to hold educational lectures for female teachers," was ranked first with a mean of 3.81 and a standard deviation of 0.94 . On the other hand, item 26 , which states that "The kindergarten utilizes a monitoring system that increases the effectiveness of its members of staff," was ranked last with a mean of 3.44 and a standard deviation of 1.o9.

Table (6) also shows that the overall mean of the items in the monitoring and follow-up dimension from the female teachers' perspective was 3.44 with a standard deviation of 0.67 , which indicates that they perceive that this dimension is receiving moderate attention. Item 27 , which states that "The kindergarten is subject to the standards of private entities," was ranked in first place with a mean of 3.57 and a standard deviation of 1.07. On the other hand, item 25, which states that "The kindergarten is keen to hold educational lectures for female teachers," was ranked last with a mean of 3.28 standard deviation of 1.14 .

These results may be attributed to the study sample's awareness of weaknesses in the control system, which is supposed to increase the efficiency of members of staff of kindergarten institutions by promoting positive behaviour to improve their performance and by using standards to monitor their performance. This means that the degree to which members of staff of kindergarten institutions practice the re-engineering of administrative processes approach can act as a catalyst for the institution to embrace change.

In addition, there is a weakness in the continuous follow-up procedures in kindergarten institutions, because these are optional, as well as a weakness in terms of the presence of standards by which to judge kindergarten institutions through the application of accountability. This is consistent with Al-Daihani (2009).

9.2 The second question: Are there any significant differences at $(\alpha \leq 0.05)$ in the degree of practicing the re-engineering of administrative processes approach in kindergarten institutions that are attributable to the academic qualification and experience variables?

To answer this question, the means and standard deviations were calculated for the various levels of the two study variables (academic qualification, experience) in respect of each of the four dimensions (planning, organization, guidance, monitoring and follow-up). Table (7) provides the results of this calculation. 
Table (7): Means and standard deviations for the degree to which kindergarten institutions practice the re-engineering of administrative processes approach according to the levels of academic qualification and experience

\begin{tabular}{|c|c|c|c|c|c|c|}
\hline Variable & Level & & Planning & Organization & Guidance & $\begin{array}{c}\text { Monitoring } \\
\text { and follow-up }\end{array}$ \\
\hline \multirow{6}{*}{$\begin{array}{l}\text { Academic } \\
\text { qualification }\end{array}$} & \multirow{2}{*}{ Bachelor's } & Mean & 3.60 & 3.58 & 3.53 & 3.47 \\
\hline & & Standard deviation & 0.60 & 0.55 & 0.59 & 0.59 \\
\hline & \multirow{2}{*}{$\begin{array}{l}\text { Bachelor's and } \\
\text { Diploma }\end{array}$} & Mean & 3.68 & 3.60 & 3.59 & $3 \cdot 52$ \\
\hline & & Standard deviation & 0.85 & 0.57 & 0.77 & 0.91 \\
\hline & \multirow{2}{*}{ Master's } & Mean & 3.88 & 3.69 & 3.65 & 3.58 \\
\hline & & Standard deviation & 0.56 & 0.52 & 0.57 & 0.55 \\
\hline \multirow{6}{*}{ Experience } & \multirow{2}{*}{$\begin{array}{l}5 \text { years and } \\
\text { less }\end{array}$} & Mean & $3 \cdot 51$ & 3.59 & $3 \cdot 54$ & 3.49 \\
\hline & & Standard deviation & 0.90 & 0.69 & 0.68 & 0.66 \\
\hline & \multirow{2}{*}{ 6-10 years } & Mean & 3.79 & 3.61 & 3.58 & 3.54 \\
\hline & & Standard deviation & 0.79 & 0.66 & 0.64 & 0.62 \\
\hline & \multirow{2}{*}{$\begin{array}{l}\text { More than } \\
10 \text { years }\end{array}$} & Mean & 3.86 & 3.66 & 3.62 & 3.56 \\
\hline & & Standard deviation & 0.74 & 0.58 & 0.63 & 0.60 \\
\hline
\end{tabular}

It is clear from Table (7) that there are apparent differences in the means. Therefore, a multivariate analysis was performed to determine the significance of these differences, Table (8) presents the results of this analysis.

Table (8): The results of the multivariate analysis of differences in the degree of practicing the reengineering of administrative processes approach in kindergarten institutions according to academic qualification and experience

\begin{tabular}{|c|c|c|c|c|c|c|}
\hline Source of variation & $\begin{array}{l}\text { Independent } \\
\text { variable }\end{array}$ & $\begin{array}{l}\text { Sum of } \\
\text { squares }\end{array}$ & $\begin{array}{c}\text { Degrees of } \\
\text { freedom }\end{array}$ & $\begin{array}{l}\text { Mean } \\
\text { square }\end{array}$ & $\begin{array}{c}\text { F- } \\
\text { value }\end{array}$ & $\begin{array}{c}\text { Level of } \\
\text { significance }\end{array}$ \\
\hline \multirow{4}{*}{$\begin{array}{l}\text { Academic qualification = } \\
\text { Wilks' Lambda (o.913). } \\
\text { The corresponding F-value = } \\
3.231\end{array}$} & Planning & $9 \cdot 75^{1}$ & 2 & 4.876 & $13.49^{*}$ & 0.000 \\
\hline & Organization & 1.588 & 2 & 0.794 & 1.362 & 0.068 \\
\hline & Guidance & 0.059 & 2 & 0.03 & 0.114 & 0.736 \\
\hline & $\begin{array}{l}\text { Monitoring and } \\
\text { follow-up }\end{array}$ & 1.856 & 2 & 0.928 & 1.564 & 0.111 \\
\hline \multirow{4}{*}{$\begin{array}{l}\text { Experience Wilks' Lambda } \\
(\text { o.912). } \\
\text { The corresponding F-value = } \\
(2.797)\end{array}$} & Planning & 3.194 & 2 & 1.597 & $3.063^{*}$ & 0.049 \\
\hline & Organizational & 2.024 & 2 & 1.012 & 1.342 & 0.264 \\
\hline & Guidance & 1.323 & 2 & 0.662 & 0.670 & 0.513 \\
\hline & $\begin{array}{l}\text { Monitoring and } \\
\text { follow-up }\end{array}$ & 0.040 & 2 & 0.020 & 0.020 & 0.981 \\
\hline \multirow{4}{*}{ Error } & Planning & 119.754 & 178 & 0.673 & & \\
\hline & Organization & 84.096 & 178 & 0.472 & & \\
\hline & Guidance & 92.812 & 178 & 0.521 & & \\
\hline & $\begin{array}{l}\text { Monitoring and } \\
\text { follow-up }\end{array}$ & 128.883 & 178 & 0.724 & & \\
\hline \multirow[t]{4}{*}{ Total } & Planning & 132.699 & 182 & & & \\
\hline & Organization & 87.708 & 182 & & & \\
\hline & Guidance & 94.194 & 182 & & & \\
\hline & $\begin{array}{l}\text { Monitoring and } \\
\text { follow-up }\end{array}$ & 132.062 & 182 & & & \\
\hline
\end{tabular}


Table (8) shows that:

There were significant differences in the planning dimension due to the academic qualification variable. It also shows that there were significant differences in the planning dimension due to the experience variable. Consequently, the Scheffe test for dimensional comparisons was used to determine the dispute. Table (9) presents the results of the Scheffe test for the academic qualification variable and Table (10) provides the results for the experience variable.

Table (9): The results of the Scheffe test for the dimensional comparisons between the means for the planning dimension according to academic qualification

\begin{tabular}{|l|l|c|c|c|c|}
\hline \multirow{2}{*}{ Dimension } & $\begin{array}{l}\text { Variable } \\
\text { Academic qualification }\end{array}$ & Mean & Bachelor's & Bachelor's and Diploma & Master's \\
\hline \multirow{3}{*}{ Planning } & Bachelor's & 3.60 & - & - & ${ }^{*} 0.28$ \\
\cline { 2 - 6 } & Bachelor's and Diploma & 3.68 & - & - & ${ }^{*} 0.20$ \\
\cline { 2 - 6 } & Master's & 3.88 & - & - & - \\
\hline
\end{tabular}

${ }^{*} \mathbf{P} \leq 0.05$

Table (9) shows that there were differences between the means of the responses of the sample subjects with a Bachelor's and those with a Master's and that the difference was in favour of those with Master's It also shows that there were differences between the means of the answers of the sample subjects with Bachelor's and Diploma qualifications and those with a Master's, also in favour of those with a Master's.

Table (10): The results of the Scheffe test for the dimensional comparisons between the means for the planning dimension according to experience

\begin{tabular}{|l|l|c|c|c|c|}
\hline \multirow{2}{*}{ Dimension } & Variable & \multirow{2}{*}{ Mean } & 5 years and less & 6-10 years & More than 10 years \\
\cline { 2 - 6 } & Experience & 3.51 & - & $0.28^{*}$ & $0.35^{*}$ \\
\hline \multirow{3}{*}{ Planning } & 5 years and less & 3.79 & - & - & - \\
\cline { 2 - 6 } & 6-10 years & 3.86 & - & - & - \\
\cline { 2 - 6 } & More than 10 years & & - & - \\
\hline
\end{tabular}

${ }^{*} \mathrm{P} \leq 0.05$

From Table (10), it can be seen that there were differences between the means of the answers of the study sample subjects with experience of ( 5 years or less) and those with experience of (more than 10 years and that the difference was) in favour of those with (more than 10 years of experience. Table (10) also shows that) there were differences between the means of the answers of the study sample subjects with experience of ( 5 years or less) and those (with 6-10 years' experience), which was in favour of those with experience of $(6-10$ years $)$.

\section{Conclusions \& Recommendations}

In light of the above results, the researcher makes the following conclusions and recommendations:

- To spread and consolidate the concept of the re-engineering of administrative processes among employees in kindergarten institutions;

- To establish a training programme on the approach to the re-engineering of administrative processes aimed at female principals and teachers in kindergarten institutions;

- To conduct further studies in other institutions and samples to broaden knowledge on the subject addressed by the present study. 


\section{References}

Ayasarah, A. \& Al - Fadil, M.M. (2006). Administrative communication and methods of administrative leadership in educational institutions, Amman: Dar Al - Hamed for Publishing and Distribution.

$\mathrm{Al}$ - Asar, S.Y. (2001). Child rearing and civilization reform from intelligence to wisdom, Conference of the role of child rearing in civilization reform 27-29 June, 2001. Cairo: Center for Childhood Studies, Ain Shams University, Center for Cognitive Studies.

$\mathrm{Al}$ - Daihani, S.G. (2009). Administrative re-engineering and the possibility of its application in the school administration in the schools of the State of Kuwait, Second Teacher Forum, Kuwait, April, 2009.

$\mathrm{Al}$ - Hamidi, M.F., Salama, S. \&Kafi, M. (2016).Re-engineering administrative processes, 1st ed., Amman: Dar Al Hamed for Publishing \& Distribution.

$\mathrm{Al}$ - Qaryouti, M.K. (2000). Organizational behaviour: The study of individual and group human behavior in different organizations, Amman: Dar Al-Shorouk for Publication and Distribution.

Hanoun, N.M.Y. (2010). "The degree of using the administrative engineering method in public schools in the West Bank Governorates, from male and female principals' point of view", (Unpublished Master Thesis).An - Najah National University, Nablus, Palestine.

Hussein, A. \& Mohammad, D. (2008). Life skills, Cairo: Dar Al - Sahab.

Hutaiba, N.F. \& Abdel Hakim, N.A. (2006). Environmental education in kindergarten, theoretically and practically, Cairo: Cairo University.

Mahamdah, N.A. (2005). Environmental education for kindergarten child, Amman: Dar Al - Safa for Publishing and Distribution.

Ministry of Education (2019).Law of the Ministry of Education for the year 1994, Department of General Education and Children's Affairs, Department of Kindergarten institutions, Amman, Jordan.

Mohammad Ziyad, M. (2009). Quality management in educational institutions, Available: www.drmosad.com/index306.htm.

Rajabion, L. Al - Shghair, F., Al - Dossary, A., Al - Maghlout, S. \& Abu Nayan, N. (2010). "Business process redesign in educational institutes in Middle Eastern Countries Case study", Issues of Information Systems, 11(1), 364372.

Rayhan, S.Y. (2014). "Obstacles in applying administrative processes engineering in public schools and ways to reduce them", (Unpublished Master Thesis). The Islamic University, Gaza, Palestine.

Thomas, I. \& Margaret, T. (2003). "Using business process re-engineering principles in educational reform". http://www.engr.iupui-edu/-no/papers/reeng.html. 